\title{
THE CONTRIBUTION OF REFORMED THEOLOGY TO HERMENEUTICS*
}

\author{
Jan H. van Doleweerd \\ STT Johanes Calvin, Denpasar
}

\begin{abstract}
Modern Hermeneutics is rooted in the realities of the readers and their culture. But what if readers are going to be their own Hermes? What kind of authority is left for the Bible as the Holy Word of God? The Calvinistic concept of autopistia, the self-convincing of Scripture, attempts to preserve the balance between tradition and inner light, between objectivity and subjectivity. It ties the Bible to God and the Holy Spirit but also to the readers and their context. With the autopistia as background this article contributes with a new hermeneutic frame with three vantage points: (1) the Text as Viva Vox Dei, (2) the reader, and (3) the historical and present hermeneutical community of readers, the church.
\end{abstract}

KEYWORDS: Reformed Hermeneutics, Autopistia, Self-Convincing Authority of Scripture, hermeneutical community, Bible reader.

ABSTRAK: Hermeneutika Modern berakar pada realita-realita pembaca dan kebudayaannya. Tetapi bagaimana jika para pembaca akan menjadi penafsir masing-masing? Otoritas macam apa yang akan ditinggalkan pada Alkitab sebagai Firman Allah yang kudus? Konsep Kalvinis tentang autopistia, kitab suci yang memiliki keyakinan pada dirinya, merupakan suatu upaya untuk menjaga keseimbangan antara tradisi dan terang internal, antara objektivitas dan subjektivitas. Hal ini mengikat alkitab kepada Allah dan Roh Kudus, namun juga kepada para pembaca dan konteks mereka.

\footnotetext{
* This article has been presented at the Reformed Evangelical International Conference, March 2016, organized by the International Reformed Evangelical Seminary, Jakarta and the World Reformed Fellowship, at Kemayoran, Jakarta.
} 
Dengan autopistia sebagai latar belakang, artikel ini berkontribusi dengan kerangka hermenutika yang baru beserta tiga posisinya: (1) Teks tersebut sebagai Viva Vox Dei, (2) para pembaca, dan (3) komunitas para pembaca di zaman historis lampau dan sekarang, yaitu gereja.

KATA KUNCI: Hermeneutika Reformed, Autopistia, Otoritas Alkitab Berdasarkan Keyakinan Dalam Dirinya, komunitas hermeneutik, pembaca Alkitab.

\section{Introduction}

It's a Reformed slogan to say that the Bible must be available for every single being. So it makes us happy to see that Bible reading became quiet popular in the churches all over the world. However at the same time modern Hermeneutics started to incorporate this new experience and developed new theories of reading, stressing the importance of the reader and the context in the process of interpretation. ${ }^{1}$ But what if readers are going to be their own hermeneutist, their own Hermes? ${ }^{2}$ And what if the word of God is losing her authority to the readers and reading communities? If so readers of the Bible become messengers of their own gods.

I think that the World Church need the contribution of Reformed opinions concerning the (1) Holy Text, (2) the reader and (3) the reading

\footnotetext{
1 Until the Reformation, Hermeneutics remains a theological auxiliary science to serve the interpretation of Scripture with methods of exegesis. In this meaning the term 'hermeneutics' is used by Heinrich Bullinger (1504-1575) and Matthias Flacius Illyricus (1520-1575). Late seventeenth century Hermeneutics becomes a broader discipline. Hermeneutics has not only to do with explaining texts, but also with the interpretation and understanding of every random act of communication, written or verbal. I use 'hermeneutics' in the sense of the theory of explanation and interpretation of texts, especially the Bible. A.C. Thiselton, New Horizons in Hermeneutics. The Theory and Practice of Transforming Biblical Reading. (Grand Rapids: Zondervan, 1992), 194; Schipani, D.S., Brinkman M., and Snoek, H., New Perspectives on Intercultural Reading of the Bible. (Amsterdam: VU University, 2015).

2 Hermes Trismegistos of the ancient Greek world is the name which is related too 'hermeneutics'. It's the name of a servant who brings the message of the gods to the people. Plato calls the interpreter 'hermèneuon' and the poet, the interpreter of gods, 'hermènès'.
} 
tradition (the church) to return to a justified balance. It's the Calvinistic concept of autopistia, the self-convincing character of Scripture that attempts to preserve the balance between tradition and inner light, between objectivity and subjectivity. It ties the Bible to God and the Holy Spirit.

Taking as starting point the autopistia of Scripture I want to contribute with a new hermeneutical frame with three variables that are strongly linked together. ${ }^{3}$

\section{The Text}

On one hand the Reformed theological focus on the literal, historical meaning of the text as well as on the sensus literalis and spiritualis are strict and inflexible. They are excellently argued and put into formulas. On the other hand the Reformed confession says that 'holy people of God spoke the Word, being motivated by the Holy Spirit'. These thoughts were expressed in one concept: autopistia. This concept professes and assumes that the Bible is God's living Voice. The Holy Spirit links himself with the written word, then it again becomes the spoken Word - viva vox Dei -, which connects the reader with the message it contains. Not autopsia, the examination of a dead body, but autopistia. Not reproductions of old truths, but those old truths become new. Working beyond the Enlightenment, this old conception corrects the tendency toward unambiguous historical explanations and interpretations of the text.

\section{The Reader}

It has become impossible to ignore the influence of the reader on the exegesis of the Bible. The invisible mental map consisting of convictions, preferences, and values - sometimes combined in the term worldview - guides

3 See also the dissertation of the author: J.H. van Doleweerd, Viva Vox Dei. Over de betekenis van de autopistie van de Schrift voor zending en Schriftuitleg in de gereformeerd bevindelijke traditie. (Utrecht: De Banier, 2012). 
people through life. A reader can never completely dissociate herself from her ancestors, education, gender, and so on. But is the Bible fair game? Can it become a sort of polluted city park where the people all leave the mess behind? However important cultures and worldviews are, they are not decisive. On the one hand, it is true that readers of different traditions, living in various circumstances, with different characters and biographical experiences, may approach a text from their own contexts. On the other hand, it is also true that Scripture, because of its autopistos character, speaks independently and contradicts, thus aiming at changes in the culture and worldview of the reader. Besides offering peace and comfort, giving encouragement and new life, the text shocks, contradicts, condemns, offers a counterbalance, and converts readers. It's a good thing it does so. There is enough in every person's life that needs to be contradicted.

\section{The Hermeneutical Community}

The church is a large hermeneutical community at all times and in all places. The explanations in Creeds and Confessions, formed in past centuries within the church, are the fruits of the continuing process of actualization and new interpretations. The Spirit was also present there. Besides searching for connection with the universal reference or the 'common sense' of the Scripture, there is another goal. It helps readers to discover blind spots and to disrupt the natural process of searching for confirmation and concurrence in Bible texts. To include the community traditions calls for critical intercontextuality. The fact that Scripture is autopistos should stimulate inclusion of the voices of other contexts and of the past in the present reading of the Scripture.

After this introduction now I will go a bit deeper into the background of autopistia and her relationship with the work of the Holy Spirit. I will highlight the distinct variables of my model. In regard to each variable, three 
vantage points will be addressed. This article will be ended by a conclusion.

\section{The Autopistia 4}

Reformed theology states that Scripture has its authority of its own (autopistia) and that is recognized through the work of the Spirit (testimonium). The Greek word 'autopistos' means 'credible in itself'. 'Pistos' has a theological connotation, something that deserves 'pistis', faith or trust. It can also be translated as 'to trust or believed'. The word 'auto' can be translated as 'by itself' or 'of itself'. Scripture is 'to be trusted because of itself' or 'in itself; it's trustworthiness is independent of external ratification. ${ }^{5}$ There is a double connotation of truth and trust in the word 'pistos'. If Scripture is autopistos, it is not only true, it also deserves our faith or trust. Therefore I prefer the translation 'self-convincing' or 'self convincingly leading to faith' ${ }^{6}$

I think that the self-convincing character of Scripture is a key for understanding of the Reformed position of Scripture. Calvin introduced the term autopistos in the final edition of the Institutes. He stated a very close connection between the self-convincing character of Scripture and the testimonium of the Holy Spirit. 'Scripture is only accepted as the Word of God through the witness of the Spirit and the Spirit gives his testimony to the Word, because Scripture deserves that certainty of itself, because it is autopistos' ${ }^{7}$

Herman Bavinck uses the term autopistos for the first time in discussing the right dogmatic method. The Christian theologian must take

\footnotetext{
4 Autopistia is used as a noun and autopistos as adverb or adjective.

5 H. van den Belt, Autopistia, 13.

6 H. van den Belt, Autopistia, 14, 316; R.A. Muller, Dictionary of Latin and Greek Theological Terms. Drawn Principally from Protestant Scholastic Theology. (Grand Rapids: Baker Bosoks, 1985), 54.

7 H. van den Belt, Autopistia, 73; J. Calvin, Institutes of the Christian Religion. $4^{\text {th }}$ ed. (Philadelphia: The Westminster Press, 1967), 1.7.5.
} 
his starting point in the Christian revelation. "Not the Church but Scripture is autopistos judex controversarium, sui ipsius interpretes. Nothing can be placed on one line with it. Church, confession, tradition, everything must be directed according to and subjected to Scripture." 8 On the other hand we see as by Calvin that also Bavinck seeks for a balance between the autopistia of Scripture and the testimonium of the Spirit. He explains the testimonium as the way in which the self-convincing Scripture gives witness to Scripture.

However in the Reformed theology the concept of the autopistia encompasses more than merely a distinctive of Scripture. It functions in a broader context in which not only the text but also the reader and his context - which includes the historical and present community called church - have their proper place. By way of four distinctives, the essentials of the doctrine of the autopistia are summarized: (1) the autopistia refers to the sovereignty of the Word, (2) the autopistia refers to the veracity of the Word, (3) the autopistia refers to the Word of the Spirit and (4) the autopistia belongs to the Word of the church. ${ }^{9}$

\section{The Autopistia and the Testimonium Spiritus Sancti}

There is one main point the concept of autopistia is related to and that's the testimonium Spiritus Sancti, translated literally 'the testimony of the Holy Spirit'. ${ }^{10}$ Here we refer to the relationship between Word and Spirit. A relationship that's difficult to bring into a simple structure. On the one hand, the Word and the Spirit coalesce. The sacred Text is the Word of the Holy Spirit, and is therefore independent, autonomous, and authoritative. On the other hand, however, there are also distinctions. The Word does not

\footnotetext{
8 H. Bavinck, Gereformeerde Dogmatiek. Deel 1, (Kampen: Bos, 1906), 1.24.

9 R.A. Muller, Post-Reformation Reformed Dogmatics, Vol. II, 256-259.H. Bavinck, Gereformeerde Dogmatiek. (Kampen: Bos, 1906); IV, 459. H. Bavinck, Gereformeerde Dogmatiek, I, 406 vv.,H. Bavinck, Gereformeerde Dogmatiek, I, 453.T. Russell, The Works of John Owen, Divine Original, 418. 10 R.A. Muller, Dictionary of Latin and Greek Theological Terms, 370.
} 
encapsulate the Holy Spirit. In the Reformed theological tradition, the subject, that is the reader or hearer of the Word, proves to be an essential hermeneutical link. The Holy Spirit, though actively working with and by means of the Word, is also considered to be active in men. It is thus presupposed that one's own unique context and life are not without significance in this process. The emphasis is on consistency between the testimonium external - the bond between Word and Spirit - and testimonium internum - the Spirit who works with and by means of the Word in the reader. ${ }^{11}$ We are to express ourselves here with three key words: the Word, the Spirit, and the reader.

Let us summarize our set of propositions. (1) The presupposition of the autopistia cannot be reduced to being applicable to the Text only, but it also

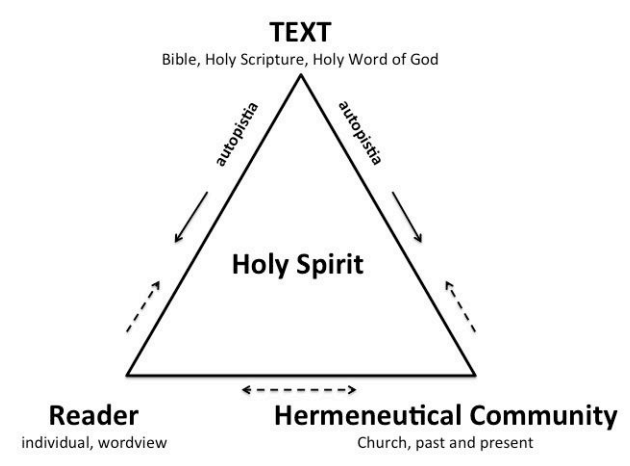
applies to the reader and the context. (2) Using the autopistia as the basis for Hermeneutics, the Bible will have the preeminence in the hermeneutical process. (3) The Holy Spirit works with and by means of the Word in the reader. Therefore, in Hermeneutics, we must speak about Word and Spirit and reader and hermeneutical community. (4) The concept of the autopistia legitimizes a Hermeneutics of trust and confidence in the Bible regardless of

11 The fifth article of the Belgic Confession says that autopistia and testimonium of the Spirit are related together: 'The Holy Spirit testifies in our hearts that they (the books of Scripture) are from God and also because they prove themselves to be from God'. J. Owen, 'The reason of faith or, the grounds whereon the Scripture is believed to be the word of God with faith divine and supernatural' in: W.H. Goold (ed.), The Works of John Owen. Vol. IV The Work of the Spirit, $6^{\text {th }}$ ed. (Edinburgh: The Banner of Truth Trust, 2004), 11; J.B. Rogers, Scripture in the Westminster Confession, A Problem of Historical Interpretation for American Presbyterianism. (Kampen: Kok, 1966), 358. 
cultural circumstances. (5) The autopistia of Scripture allows room for untrained readers to read the Bible fruitfully, but it does not leave them to themselves. (6) The hermeneutical triangle, as described here, legitimizes a plea for the use of our confessional heritage in reading the Bible. (7) The autopistia legitimizes fluidity in hermeneutical methodology to arrive at an explanation, interpretation and application of the text.

\section{Text, Reader and Hermeneutical Community (Church)}

The hermeneutical triangle rooted in the view of the Scripture as having autopistia and distinguished by the Reformed theological propositions before, has to be augmented with guidelines to make it to a well-balanced instrument. Therefore I link each variable with three advantage points related to old and new hermeneutical findings.

Text: (1) an eternal Author, (2) a universal scope, (3) explanation, interpretation and application.

Reader: (1) the reading method: multi-faceted reading, (2) the reading attitude: in submission to the Scripture, (3) the cultural framework.

Hermeneutical community: (1) the church as a reading community, (2) 'Wirkungs-und Rezeptionsgeschichte', (3) the confessional heritage.

\section{Text: an Eternal Author (1)}

The Bible is an ancient text, composed of many texts by various authors from various periods. Nevertheless, the Reformed tradition sees them as authors of one book. This unit is to be traced back to God the Holy Spirit, the first and eternal Author of Scripture. Reformed Hermeneutics opposes the radical decapitation of the author and the complete shift of the 
meaning of the text to the interpretation of the reader.12 For the Reformed, hermeneutics is the author of importance. He meant something to write and what he meant to say is a guide for the interpretation of the text. But is it important to reconstruct completely the original historical situation? Is it necessary to discover the hidden intentions of the author?

Reformed Hermeneutics emphasize the intention of the text. What the message is and what the author has written in form and content is the road towards it. But because there is the Holy Spirit behind the text, the indispensable link in the understanding of the mystery of the text, there can never be a one-sided emphasis on the writer of the Bible. Therefore we can agree with Paul Ricoeur as he points to the communicative nature of the text: 'The reader is absent from the act of writing, the writer is absent from the act of reading. The text thus produces a double eclipse of the reader and the writer. It thereby replaces the relation of dialogue, which directly connects the voice of one to the hearing of the other' ${ }^{13}$

The autopistia of Scripture is relevant here. Scripture speaks through the witness of the Holy Spirit in and through the text. Through the witness of the Holy Spirit the text, the implied reader and the actual reader of flesh and blood are united. A Reformed hermeneutist will not end by studying one text or pericope. He wants to connect it with the network of all other texts in the Bible, thereby seeking the intention of not only writers, but also above all the Author, the Holy Spirit who inspired them to write the words of God.

12 A.C. Thiselton, New Horizons in Hermeneutics, 515; K.J. Vanhoozer, Is There a Meaning in This Text? The Bible, The Reader and the Morality of Literary Knowledge (Grand Rapids: Zondervan, 1989 (2009)), 47.

13 P. Ricoeur, Hermeneutics and the Human Sciences (Cambridge and New York: Cambridge University Press, 1981), 139. 


\section{Text: a Universal Scope (2)}

The autopistia of Scripture confirms the assumption that the past and present have a universal reality and that the same things bother in the twenty-first century as in the days of the Bible writers. The distance between then and now is covered by the remaining witnesses of the first and only Author of Scripture. Therefore we don't need a hundred per cent identification with the original situation of the writers and the audience. From this perspective, there is no objection to the idea of Ricoeur, which characterizes language as a language event of 'instance du discourse'. The sentences of the text have meaning in the past and in the present. ${ }^{14}$

A universal scope runs from the creation of heaven and earth and the fall of man, through the history of the nation of Israel to the birth of Jesus Christ, the Son of God and from there through Calvary to the world and its nations with the proclamation of salvation in Christ. When talking about these issues, the Bible has a unanimous intent, although texts can sound polyphony.

\section{Text: Explanation, Interpretation, and Application (3)}

Explain, interpret and apply can be seen as successive phases in the hermeneutical process. Explanation belongs to the text side and interpretation and application belong to the reader side. This means that the interpretation and application of the text always have to relate in one way or another to the possibilities that are given in the text itself. ${ }^{15}$

Why are explanation and application mediated by interpretation? The modern hermeneutics shows us that reading is not merely a rational

14 Paul Ricoeur has underlined the character of discours of language. 'Sentences - language as used, language as discourse - connect words "in a synthesis which goes beyond the words".' In: K.J. Vanhoozer, Is There a Meaning in This Text?, 204.

15 A.C. Thiselton, New Horizons in Hermeneutics, 495-503, 515-523. 
cognitive process, but interpreters are people who are guided by their own needs, values and interests. It is for this reason that every reader should be aware of not only the text, but also of the interpretation process and his or her own assumptions. The text is the Other, which is outside our own interests. Reformed Hermeneutics proposes an ethics based on listening, trusting and respecting the text, both with heart and head. On the one hand seriously listening to the voice of the original writer and on the other hand taking a critical assessment of preconceptions and interests. ${ }^{16}$

In our model, the text has a great potential and strength. However, these are not dependent on the extent to which the initial setting can be reconstructed by exegesis. In many cases it is not even possible to reconstruct approximately. The literal, historical meaning of the text and the methodical exegetical approach is indeed the starting point in the interpretation process, but the text is autopistos and therefore it is not necessary to keep the text outside of the reader. Does this not encourages the reader to read his individual historical pain and difficulty in Scripture and therefore drowns out the voice of the Word? Ultimately, this can never be prevented, not even by a thorough exegesis. Precisely by connecting with each other text and reader and hermeneutical community can be corrected sidedness. In view of the place and function of the Holy Spirit in the hermeneutical process, there may never be a strict division between exegetical explaining and the interpretation and application of the text.

The text thus really comes alive when the interpreter is going to participate in the text. But there are not only a text that reflects a historical situation and a reader with a limited understanding framework. There is also the reading tradition of the church that plays a significant role in our

16 See G.A. Phillips, ‘The Ethics of Reading Deconstructivily, or Speaking Face-to Face: The Samaritan Woman Meets Derrida at the Well' in: E.V. McKnight, E. Struthers Malbon (eds.), The New Literary Criticism and the New Testament (Valley Forge: Trinity Press International, 1994), 283-325. 
model. ${ }^{17}$ The hermeneutical process consists of an encounter between these three elements. To summarize, the reader first has to pay attention to the text attributes. But also the reader pays explicit attention to his own values, beliefs and preferences and confronts himself with the text. Next, the reader pays explicit attention to the context and the reading tradition of the church. Then takes stock: the Spirit leads to application and appropriation or the meaning is hidden and the text is rejected.

\section{Reader: The Reading Method: Multi-faceted Reading (1)}

Modern Hermeneutics distinguishes between the text and its properties and the reality that creates the reader with the text. The readerresponse theory points out the impact that the reader unnoticed exerts on the interpretation of the text. ${ }^{18}$ Also from psychoanalysis has been clearly shown that many processes are put into effect in the reader when reading texts. 'Defences, Expectations, Fantasies and Transformations' play a role in reading texts. Readers tend to disregard certain characteristics or events in texts and to blow others. In order to prevent (1) the content of the text, and all that can be explained from it, (2) their readers own interpretation and application, and (3) the interpretation of the hermeneutical community have to be confronted with each other. A reading process characterized by this interaction neutralizes unbalanced dominant performance. If the reader is confronted with a strange explanation, he is forced to open her- or himself. In this manner fundamentalism is prevented. The input of an explanation from another culture brings the reader into contact with other interpretations. The autopistia legitimizes such an interaction process.

\footnotetext{
17 K.J. Vanhoozer, Is There a Meaning in This Text?, 106.

$18 \mathrm{U}$. Eco, The role of the Reader. Explorations in the Semiotics of Texts (Bloomington: Indiana University Press, 1984); D.S. Schipani, M. Brinkman and H. Snoek, New Perspectives on Intercultural Reading of the Bible (Amsterdam: VU University, 2015).
} 
Reader: The Reading Attitude: in Submission to The Scripture (2)

In the Reformed tradition repentance of man through Word and Spirit is of great importance and is directly linked to Bible-reading. A text can be approached from different motives. A reader can do this from a particular scientific interest, or an existential need, or just from curious interest, but in the opinion of Reformed Hermeneutics real Bible-reading takes place when there is faith working through repentance. This faith not only holds true the content of the entire Bible and not only accepts the Bible as authoritative Word of God, but she also works trust in the reader that he or she receives salvation by the Holy Spirit only because of the merits of Christ. ${ }^{19}$ We are dealing here with the soteriological point of reading the Bible. Repentance is linked to the postulate of the Reformed theologian that every reader of the Bible, without this conversion - read: regenerating and illuminating action of its first author, the Holy Spirit - he cannot really understand the Scripture. ${ }^{20}$ In this context, the hermeneutist talks about the 'death of the reader', which means that the reader's own vision must be submitted to what he encountered in the text. ${ }^{21}$ So understanding of the Bible bears the marks of an inner struggle, 'a struggle between sense and self' or with the words of Ricoeur: 'Reading is first and foremost, a struggle with the text'. ${ }^{22}$

Because Scripture is autopistos, she works conversion. Therefore, Reformed Hermeneutics can also be called a 'transforming Hermeneutics'. ${ }^{23}$ The Holy Spirit, the interpreter of Scripture transforms readers through the

\footnotetext{
19 Heidelberg Catechism, Lord's Day 7, question and answer 21.

20 Canons of Dordt, Cap. III and IV, art. 12.

21 J.H. van Doleweerd, 'The living Voice of the dead to the dead', in: H. Snoek (Ed.), In love with the Bible and its ordinary readers. Hans de Wit and the intercultural Bible reading project (Indiana: Institute of Mennonite Studies, 2015).

22 K.J. Vanhoozer, Is There a Meaning in This Text?, 407; P. Ricoeur, A Ricoeur Reader, Reflection and Imagination. Edited by M.I. Wallace. (Minneapolis: Fortress. 1995), 494.

${ }_{23}$ Because of this reason Thiselton's New Horizons in Hermeneutics is subtitled: 'The Theory and Practice of Transforming biblical Reading'.
} 
Word. However, although conversion is a result of reading or hearing the text, it's not a precondition.

\section{Reader: The Cultural Framework (3)}

Every society has a culture and all people are profoundly affected by their own culture. Culture provides the person a personal and collective mind road on the world and provides interpretation of reality. ${ }^{24}$ Being a member of a different culture means to have different thoughts, to exhibit other behaviours, to cherish different opinions about almost everything that belongs to human life.

It is important to understand that in the hermeneutical process the cultural frame of the reader plays a major role in the interpretation. It is an invisible mental map consisting of beliefs, preferences and values, sometimes summarized by the term worldview that guides people through life. ${ }^{25}$

But how important they are, culture and worldview are neither prescriptive nor immutable. Its content is in the state of change, which sometimes can go fast. While on the one hand it is true that readers from different traditions, living in different circumstances, with different characters and biographical experiences are interpreting a text from all kind of different perspectives, it is on the other hand also true that Scripture, because of her autopistos character, speaks universal and independently. She makes the Word powerful to change culture and worldviews.

Although the church of the 21st century has a large amount of interpretation of Scripture at its disposal, not every thing is explained,

24 C. Geertz, The Interpretation of Cultures, New York 2000 edition. C. Geertz, Available Light. Anthropological Reflections on Philosophical Topics. (Oxford/Princeton, 2001).

25 P.G. Hiebert, Transforming Worldviews: An Anthropological Understanding of How People Change (Grand Rapids: Baker Academics, 2008).; P.G. Hiebert, Anthropological Insights for Missionaries (Grand Rapids: Baker Academics, 2008) (23rd Printing). 
interpreted and applicated. In this context we speak about the eschatological character of Scripture. The fulfilment of its meaning and intention has to come to the consummation. In this eschatological event past and present are included. This is her goal (telos): The Word as a message of God's deeds should help to achieve the objective set by Him, namely, that all nations will share in salvation.

May living conditions and culture join in the interpretation of the text? In our model, in which the autopistia of Scripture is carried over to the reader and the hermeneutical community of all time and in all places, mankind is addressed in his own living conditions. This means that circumstances of the reader on the side of the interpretation and application must play a role. Otherwise Scripture would not be meaningful in the life of the reader. Contextuality is not a restriction, but enrichment. So every reader, reading the history of the people of Israel after crossing the Red Sea, needs to fill in for herself what she encounters in life as bitter water causing her to rebel against God.

\section{Hermeneutical Community: The Church as a Reading Community (1)}

It is not about the church as an organization, though it is impossible to neglect. But the emphasis lays on the Word in the community. That community can be shaped in various ways, for example by reading a pericope and looking for the explanation, interpretation and application. It could also be that people come together around the Bible having one person in charge to guide in the explanation. That community can be experienced in individuality with other readers and commentators who have entrusted their explanations to the paper. The point that matters is that there is a fundamental openness to the historical and current reading community, even if intercultural dialogue is practically poorly realized, the language barrier a high threshold and the Christian reading community deeply 
divided over what they read in the Bible. The historical and current reading community is important because the Scripture cannot exist without a reading community because of the supposed link between living the Word, the Spirit and the readers. No one can read the Bible for the first time and pretend he or she is the first.

Hermeneutical Community: 'Wirkungs-und Rezeptionsgeschichte' (2)

The church is a 'hermeneutical community'. Personal trust in the truth is based on the Scripture itself, but it has an assurance in the testimony of many other Christians in different times and contexts. This is what hermeneutists call 'Wirkungs- und Rezeptionsgeschichte'.

In addition to the purpose that the tradition confirms our interpretation and application, and enhanced measures to find and join the universal reference and the common sense of Scripture, there is also another purpose. The frame of reference of every human being is strongly influenced by the community to which they belong. Only setting up a specific pair of glasses can give access to a text. People cannot escape from the framework of their group. ${ }^{26}$ Thiselton speaks about 'horizons of expectations which have been derived from, and shaped by, the communities to which the individual reader belongs: indeed a community of communities, ranging from the local church and church traditions to learning- processes and assumptions inherited through the family, school and mass media, contributes decisively to this horizon of expectation'. There are, alongside recognizable features, also strange unknown elements in the interpretation of other Christians. It then goes about other experiences in other church traditions and living conditions. In this latter case could be included acute distress, permanent suffering, and persecution and extreme poverty. Sensitivity to strange

26 A.C. Thiselton, New Horizons in Hermeneutics, 531, 532; K.J. Vanhoozer, Is There a Meaning in This Text?, 28. 
elements can significantly deepen and enrich the hermeneutical process.

Christians of other times, living in different circumstances came to very different interpretations. It is not desirable to close our eyes to this. The supposed incompetence of man to understand the Scripture by natural light makes us humble and encourages us to search for the witness of the Holy Spirit. ${ }^{27}$

\section{Hermeneutical Community: The Confessional Heritage (3)}

Speaking of the church in the past has a concrete face in the Creeds and Confessions ${ }^{28}$, which came into being after a long process of

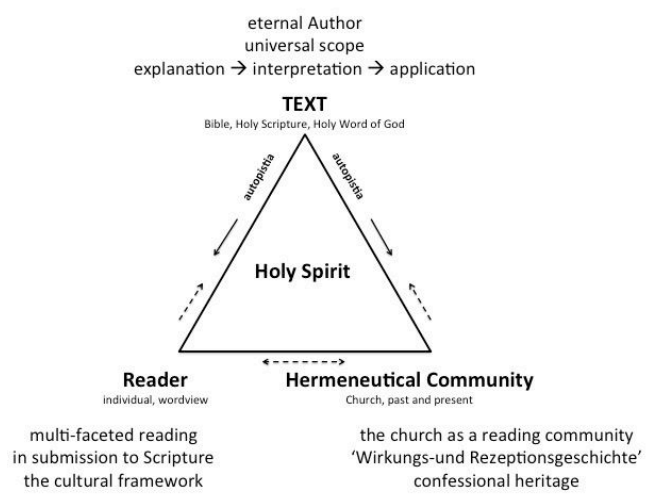
interpretation of Scripture and were accepted by the authority of the church. In that way biblical interpretation by early readers was made functional in the life of the church. It is impossible to ignore in the hermeneutical process the Creeds and Confessions of the church. To do this would make silence the voice of historical and current interpretation communities. In the Reformed tradition Confessions of the Church are always considered as the

27 D. Kroneman speaks in this context about 'inter-contextual dialogue': 'All interpretation is contextual. On the one hand, our context functions as a lens that helps us to understand a text better. On the other hand, our context functions also as a filter that blinds us to certain aspects of the text and of the meanings it intends to convey. In order to overcome our own hermeneutical limitations, inter-contextual dialogue is very much needed. Inter-contextual dialogue is important to avoid interpretational errors'. D. Kroneman, Text, Context, Intertextuality, and Intercontextual Dialogue. Towards an Ethics of Hermeneutics and Interpretation (Dallas: Bible Translation Conference Wycliffe, 2011), 16.

${ }^{28}$ In Reformed theology we are speaking about Oecumenical Creeds and Reformed Confessions; Schaff, P., The Creeds of Christendom, $6^{\text {th }}$ ed. (New York, 1919). 
'Amen' of the Church on the revealed Word of God. A unilateral appeal to Scripture with rejection of these confessions is tantamount to ignoring the ministry of the Holy Spirit. At the same time the church never gave a divine authority to her confessions. They should be subjected to the Word of God. Confessions are not canonical and they are basically open for replenishment.

In the Reformed tradition confessions of faith are considered important because they express the unity of the church in her true faith in Jesus Christ. Calvin had the following articulated in the foreword of his Catechism of Geneva: 'First, In this confused and divided state of Christendom, I judge it useful that there should be public testimonies, whereby churches which, though widely separated by space, agree in the doctrine of Christ, may mutually recognize each other. With this view, bishops were wont in old time, when as yet consent in faith existed and flourished among all, to send Synodal Epistles beyond sea, by which, as a kind of badges, they might maintain sacred communion among the churches. How much more necessary is it now, in this fearful devastation of the Christian world, that the few churches which duly worship God, and they too scattered and hedged round on all sides by the profane synagogues of Antichrist, should mutually give and receive this token of holy union, that they may thereby be incited to that fraternal embrace of which I have spoken?'29

\section{Conclusion}

I conclude that given our present situation, with more than thirty per cent of the world considering itself as Christian and considering the Scripture as being normative for them, the hermeneutical model as

29 http://www.reformed.org/documents/calvin/geneva_catachism/geneva_catachism.html - 3 March 2016. 
presented in this article, is a tool of vital importance. It is both orthodox and modern: Orthodox because it pleads for a traditional view regarding the Bible as being the Word of God - a Word that is autopistos in nature and it allots significance to the historical context in which the Word was read and explained; and modern because of the significance of the reader in the hermeneutical process, the cultural and conceptual elements that he or she inserts into the process and the hermeneutical relevance of the context in which the Bible is being read worldwide.

The autopistia of Scripture allows for a hermeneutical model in which not only the text and the historical or current context determines the interpretation, but also the reader and the context together, with a deep respect for the Word of God as having supreme authority. Inexperienced readers are not left to fend for themselves, but rather, are immersed into the reading tradition of the church, doing so without the immediate manipulation of the meaning of the text. This does not imply in any way that the historical and current ecclesiastical context 'rules over' the Bible, since these contexts are also subjected to the authority of Scripture. Hermeneutical anarchy occurs when the meaning of a text is put squarely into the hands of the reader. This will result in hermeneutical totalitarianism, being the result of an interpretation that is imposed upon the context. By way of the model being offered here, biases as well as a lording over others will be avoided and opposed.

Finally, a Reformed Hermeneutics doesn't offer a simple Hermeneutics. It is not easy to adopt a hermeneutical method that aims to a balance between the Holy Text, the reader and the hermeneutical community. Reformed theologians have never shunned difficulties in their academic work. While you can lean toward looking for the convenience of constant and coherent wording in dogmatic theology, this is impossible in Hermeneutics. One must constantly form a bridge from explanation to interpretation to application. The Text, its contents and meaning must be 
brought to life through the filter of the worldview of the hermeneutist. This is a flowing process in which the Spirit must play a role. Here, in this uncomfortable situation we found ourselves time and again. There is no easy Hermeneutics, just as life is not easy. But it does not diminish our trust in the Holy Book. Scripture resides among the cultures as the living voice, the Viva Vox Dei. 


\title{
THE PARADISE IN WILDERNESS: AN EXEGETICAL APPROACH ON MARK 1:9-13 AND ITS SIGNIFICANCE IN CONTEMPORARY SOCIETIES*
}

\author{
Jack David Kawira \\ Theologische Universiteit Kampen
}

\begin{abstract}
Adam brings humanity from paradise to wilderness by his disobedience toward God. Since then, humanity endures countless sufferings in this world and eternal damnation because of sin. But Christ as the second Adam brings himself from paradise to wilderness in order to bring his people from wilderness to paradise by his perfect obedience. Since then, his people not only have the assurance of eternal salvation but also have the possibilities to exercise paradise in the wilderness with Him. Even more, by the power of the Holy Spirit, his people will accomplish their calling as disciples by witnessing paradise in the wilderness contemporary societies to point them to Christ. An exegetical approach on Mark 1:9-13 gives us a strong foundation to discuss the nature of wilderness and its challenges, followed by the Paradise motive which is exclusive to Mark. The significance of the discussion will bring light to explain why so many prophets and apostles exercise real joy in the face of great suffering and tribulation. And of course, from the discussion it is also true for his people in the present and future to exercise or even more to bring paradise into the wilderness by the grace of God.
\end{abstract}

KEYWORDS: Paradise, Wilderness, Joy, Suffering, and Wilderness Contemporary Societies.

\footnotetext{
* This article has been presented at the Reformed Evangelical International Conference, March 2016, organized by the International Reformed Evangelical Seminary, Jakarta and the World Reformed Fellowship, at Kemayoran, Jakarta.
} 
ABSTRAK: Adam membawa umat manusia dari Firdaus ke padang gurun oleh ketidaktaatannya kepada Tuhan. Sejak saat itu, umat manusia mengalami penderitaan yang tidak terhitung di dalam dunia dan mengalami hukuman kekal karena dosa. Tetapi Kristus sebagai Adam kedua membawa diri-Nya dari Firdaus ke padang gurun untuk membawa umat-Nya dari padang gurun ke Firdaus oleh ketaatan-Nya yang sempurna. Sejak itu, umat-Nya bukan hanya memiliki kepastian akan keselamatan yang kekal tetapi juga memiliki kemungkinan untuk mengalami firdaus dalam padang gurun bersama dengan-Nya. Bahkan, dengan kuasa dari Roh Kudus, umat-Nya akan menggenapi panggilan mereka sebagai murid dengan menyaksikan firdaus dalam komunitas kontemporer padang gurun untuk membawa mereka kepada Kristus. Pendekatan eksegesis pada Markus 1:9-13 akan memberikan dasar yang kuat untuk mendiskusikan sifat dari padang gurun dan tantangannya, diikuti dengan motif firdaus yang khusus bagi Markus. Signifikansi dari pembahasan tersebut akan memberikan terang untuk menjelaskan mengapa banyak nabi dan rasul mengalami sukacita sejati ketika berhadapan dengan penderitaan yang berat dan penganiayaan. Dan tentu saja, dari pembahasan tersebut umat-Nya baik saat ini maupun yang akan datang akan mengalami atau lebih lagi untuk membawa firdaus kedalam padang gurun dengan anugerah dari Tuhan.

KATA KUNCI: Firdaus, Padang Gurun, Sukacita, Penderitaan, and Komunitas Kontemporer Padang Gurun.

\section{Introduction}

In Genesis 2:8, it is mentioned that the Lord planted a garden in Eden.

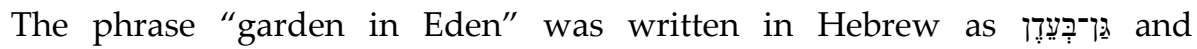

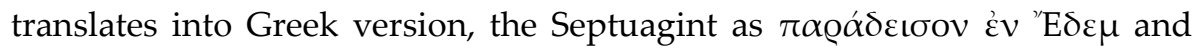


then translates into English as paradise. ${ }^{1}$ The word parádeisos is used in several passages in the Bible both the Old Testament such as Genesis 2:8,10; Isaiah 51:3 and in the New Testament such as Luke 23:43; 2 Corinthians 12:4 and Revelation 2:7 which bring light to the understanding of paradise. First of all, in Genesis 2:8-17 Paradise has a meaning as God's garden where he put the human being to work, worship and to keep it according to his law. As long as Adam lives in perfect obedience toward God, humanity may live in the paradise. And when he disobeys God, God cast humanity out from paradise to wilderness (Genesis 3:24) with punishment as what God says to Adam in Genesis 3:17-19. Because of that, paradise is the reverse condition of wilderness, where it is not only talking about the place but also the condition to live in harmony towards God, to live in the very presence of the Lord according to his law.

Furthermore, the important features of the Genesis paradise regarding the tree of life and its rivers will lead the discussion to the description of paradise in the book of Revelation (Revelation 2:7; 22:2, 14, 19). The Revelation paradise still consists of the tree of life and its rivers (Revelation 22:14). And the fruit of the tree of life will be given as a reward to his people who hear what the Spirit says (Revelation 2:7) and punishment for those who reduce the word of God (Revelation 22:19). The connection between Genesis and Revelation Paradise gives an eschatological understanding towards paradise more abundantly, even for the Genesis paradise. But there are slight differences between the eschatological structure of creation and recreation in Revelation.

In the creation, Adam can "possibly" live for eternity in the paradise by his obedience. Sarna says that "man was created from perishable matter, was mortal from the outset but that he had within his grasp the possibility of

1 Nahum. M. Sarna, JPS Torah Commentary: Genesis, (Philadelphia: Jewish Publication Society, 1989), 18. The word parádeisos originated in the Old Persian pairi-daeza, meaning "an enclosed park, a pleasure ground" where it referred to the royal park of the Persian kings. 
immortality, where the fruit from the tree of life was understood to bestow immortality upon the eater." 2 Because of that, Adam in God's time will receive the rewards from this tree as well as being depicted in the book of Revelation if he passed the probation. Unfortunately, he failed, and by his disobedience he causes humanity to be expelled from paradise to wilderness and death. As the result, the eschatological scheme now moves towards the need of redemption in Jesus Christ, to bring all believers to the paradise, where we can live in eternity with the perfect relationship towards God, as what Jesus says towards the penitent thief on the cross in Luke 23:43 "Truly, I say to you, today you will be with me in Paradise." It is very clear that Jesus guarantees this man would be with him immediately after his death. Louise Berkhof said that to be with Christ also means to be with him in heaven. ${ }^{3}$ It is because the New Testament clearly identifies paradise with heaven in 2 Corinthians 12:2,4 where "paradise" is used synonymously with "the third heaven" in this account. ${ }^{4}$

Moreover, the restoration not only speaks of the human being from mortal to immortal but the Bible also talks about the restoration or recreation of heaven and earth. The promises reveal very clearly in Isaiah 51:3 "For the LORD comforts Zion; he comforts all her waste places and makes her wilderness like Eden, her desert like the garden of the LORD; joy and gladness will be found in her, thanksgiving and the voice of song." 5 It is the condition where the heaven and earth will be renewed and no geographic distinction between heaven and earth as what in the Book of Revelation shows that the new Jerusalem will come down from heaven to earth (Revelation 21:2,10) and forms the eternal dwelling place of God and his

\footnotetext{
2 Ibid., 18.

3 Louis Berkhof, Systematic Theology, (Grand Rapids: Eerdmans, 1938), 679.

4 Ibid., 683.

5 The Septuagint version on Isaiah 51:3 used the word $\pi \alpha \varrho \alpha \delta \varepsilon \varepsilon \sigma o v$ or paradise both on the word Eden and garden.
} 
people, where the new earth will be a place of perfect righteousness (Isaiah 51:6), divine kindness (Isaiah 54:10), an eternal relationship with God (Isaiah 66:22), and total freedom from sin (Romans 8:21). ${ }^{6}$

\section{The Redemption}

When Adam disobeys God, humanity is not only cast out from paradise to wilderness with a broken relationship with God but also enter into damnation in death and suffering. The angels who, before his transgression, had been appointed to guard him in his Eden home, were now appointed to guard the gates of paradise and the way of the tree of life, lest he should return, gain access to the tree of life, and sin be immortalized. ${ }^{7}$ The concept of work which is delightful in the worship towards God at first (Genesis 2:15), now shifted and becomes a burden because the land was cursed. The humanity in Adam now is hopeless and doesn't have anything good in them to regain this lost. Just like what Augustine says about the will of human being, before the fall Adam has the ability not to sin (posse non pecarre) and the ability to sin (posse pecare), but after the fall Adam only has the possibility of not being able not to $\sin$ (non posse, non peccarre) ${ }^{8}$ and also lost the ability not to die (posse non mori). ${ }^{9}$

From that moment, humanity endures countless of sufferings, burdens, and struggles in the wilderness. But gratefully, because of God's love, He brings light and hope by giving His only Son, Jesus Christ, for all whoever believe in him may not perish but have eternal life (John 3:16). In the perfect obedience, willingness and loves towards the Father, Jesus Christ

\footnotetext{
6 Elwell, Walter A., and Barry J. Beitzel. Baker Encyclopedia of the Bible, (Grand Rapids: Baker, 1988), 1547.

$7 \quad$ Ellen Gould White, Confrontation; Redemption; or the Temptation of Christ in the Wilderness (Review and Herald Publishing Association, 1971; 2002), 15.

8 Sproul, R. C. Can I Know God's Will? Vol. 4, (Lake Mary: Reformation Trust Publishing, 2009), 34.

9 Stevenson, J., \& Kidd, B. J. (Eds.). Creeds, councils, and controversies: documents illustrative of the history of the church A.D. 337-461, (New York: Seabury Press, 1966), 232.
} 
descends from the very presence of the Father or paradise to the wilderness. Amazingly, we can see the scheme of salvation here in the perspective of paradise-wilderness framework, where Adam by his disobedience is expelled from paradise to wilderness with an inability to regain his loss, and because of that Christ descends from paradise to wilderness in order to bring his people back to the paradise.

\section{The Paradise in Wilderness in Mark 1:9-13}

In Mark 1:9-13 in the account of Jesus baptism and temptation, we can see two aspects which confirm that the presence of Jesus Christ brings paradise in the wilderness. First, it is because the account of Jesus baptism shows how perfect his relation with the Father and the Holy Spirit is, which in the second account is tempted by Satan in the wilderness. Second, Mark uses paradise motives in this account to show the superiority of Jesus Christ who overcomes Satan in the wilderness. ${ }^{10}$ And because of that, we will discuss these two accounts in the perspective of paradise in wilderness framework. By this understanding, his disciples in the wilderness can also experience the paradise in the present time because of our relations toward Jesus Christ reconcile us to the Father which is applied by the Holy Spirit. Moreover, his disciples not only experience paradise in the wilderness but also show and bring the paradise in the wilderness contemporary societies as we are going to discuss.

\section{Outline and Structure Analysis}

It is important for us to have an analysis towards the outline and structure of Mark before having further discussion about these two accounts

10 William L. Lane, The Gospel According to Mark: the English Text with Introduction, Exposition, and Notes (the New International Commentary On the New Testament), (London: Eerdmans, 1974), 61. 
because by doing this we can understand the importance about these passages compared to all accounts in the gospel of Mark. The outline below was arranged with Jesus Christ as the focus. ${ }^{11}$

I. Introduction (1:1-15)

II. Demonstration of Jesus' Authority (1:16-8:26)

III. Testing Jesus' Authority in Suffering (8:27-16:8)

With this outline, we can understand that the position of Jesus baptism and temptation were in the introduction section which is framed by two accounts of John the Baptist. Mark 1:1-8 shows how John the Baptist fulfilled Isaiah's prophecy as "the voice of one crying in the wilderness." $\mathrm{He}$ prepares the coming of the Lord in the wilderness, by proclaiming a baptism of repentance for the forgiveness of sins. And when the Lord comes at the moment of baptism a voice comes from heaven, "You are my beloved Son; with you, I am well pleased." These two voices connect and anticipate that only through Jesus, the beloved Son of the Father, the repentance and forgiveness of sins may be applied. And after that, Mark 1:14-15 shows that after John was arrested Jesus started his ministry. William Lane also gives an interesting arrangement of Mark 1:1-13 as we can see below with geographical approach. ${ }^{12}$ This approach will give an interesting emphasis in the gospel of Mark, especially for the wilderness theme which is crucial in this gospel.

I. Prologue to the Gospel (1:1-13)

1. The Herald in the Wilderness (1:1-8)

2. The Lord in the Wilderness (1:9-11)

3. Temptation in the Wilderness (1:12-13)

The structure analysis of these two accounts will show more clearly the emphasis of the gospel of Mark, just as what E.W Bullinger tries to show

11 ESV Bibles by Crossway, Esv Study Bible, Personal Size (Wheaton: Crossway, 2012), 1891.

12 William L. Lane, Mark, 29. 
the chiastic structure upon these two accounts, as we can see below the chiastic structure of Jesus baptism and Jesus temptation. ${ }^{13}$

The Baptism: With Water

C ${ }^{9}$ The Lord. His coming to John.

D 10_- Seen. The heavens opening.

$D \_10$. Seen. The Dove descending.

$C^{11}$ The Lord. The voice coming to Him.

The Temptation in the Wilderness

E12 The Spirit. Compulsion

F13_- Satan. Temptation

F-13. Wild Beast. Companionship

E_-13. The Angels. Ministration

From these chiastic structures, we can see the emphasized point of view, first in verse 10, where the heavens are torn open, and the Spirit descends on Jesus like a dove and second in verse 13, where Mark gives a contrast between wilderness motives and paradise motives.

\section{The Baptism of Jesus}

From the outline and structure analysis above, the baptism of Jesus Christ by John the Baptist was held in the wilderness context. On the other side, the act of John the Baptist prepares the way of the Lord who has the perfect relationship towards the Father and the Holy Spirit, and it is also the act to prepare the coming of the paradise. It is because his voice in the wilderness, proclaiming a baptism of repentance for the forgiveness of sins is answered by the voice from heaven or paradise which mentions that Jesus is his beloved Son, whom He is well pleased. Furthermore, on verse 10, we can also see the other antithetical structure right in the center of the chiastic

13 E. W. Bullinger, Companion Bible: King James Version, Burgundy, Bonded Leather, Burgundy Bonded Leather ed. (Grand Rapids: Kregel Publications, 1990), 1382-83. 
structure in the account of Jesus baptism. Lane says that many had come to the Jordan to be baptized by John, but only in the instance of Jesus, in whom true submission to God was perfectly embodied, was the "coming up" from the water answered by a "coming down" from above. ${ }^{14}$ Both antithetical structures anticipated Jesus Christ ministry in the perfect obedience towards the Father until his death on the cross to accomplish the work of salvation. It means that only through him forgiveness of sins may apply, and his people may experience the foretaste of paradise in the wilderness because the relationship towards the Father is restored in Christ.

The other elements which strengthen the paradise and wilderness motives in this account are implied in several phrases or word that is used by Mark such as "heavens being torn open," "the Spirit descending like a

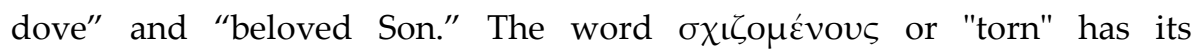
background in Isaiah 64:1 and Jewish tradition elaborates Isaiah's imagery in the Testament of Levi composed perhaps in 250 B.C., which anticipates the account of Jesus baptism in Mark, as we can see below.

The heavens will be opened, and from the temple of glory sanctification will come upon him, with a fatherly voice, as from Abraham to Isaac.

And the glory of the Most High shall burst forth upon him.

And the spirit of understanding and sanctification shall rest upon him [in the water].

For he shall give the majesty of the Lord to those who are his sons in truth forever. ${ }^{15}$

It has significant meaning because, in the second temple Judaism period, it is commonly believed that there are no longer any prophets of Old Testament because the Holy Spirit already stops talking to his people. By the absence of the Holy Spirit, there are no prophecies, and because of that the

14 William L. Lane, Mark, 55.

15 James R. Edwards, The Gospel According to Mark, The Pillar New Testament commentary (Grand Rapids; Leicester: Eerdmans; Apollos, 2002), 35. 
phrase "heavens being torn open" inaugurates the long-awaited return of God's Spirit. A period of grace begins in Jesus, to whom God reveals himself in the world in an unparalleled manner. ${ }^{16}$ Watts also said that this part has the new exodus motives in relation towards Isaiah 64:1, and in Jesus the long awaited new exodus has begun with the power to rescue his people. ${ }^{17}$ If we compare to the first Exodus, God could not come down until the people of Israel consecrated themselves (Exodus 19:10). But on the new Exodus marked by the heavens being torn open, God came down and gave his confirmation that the sonship has been re-established through the one true Israelite whose on behalf of many expressed a perfect repentance. ${ }^{18}$

The phrase "the Spirit descending like a dove" has its analogy rooted in the OT or post-biblical Judaism. Genesis 1:2 has an implicit allusion, where the brooding of the Spirit over the waters at creation suggested to Ben Zoma (ca. A.D. 90) the action of a dove. And the descent of the Spirit signifies new creation, corresponding to the cosmic overtones in the rending of the heavens. ${ }^{19}$ The dove also serves as a symbol of the community of Israel, and the descent of the Spirit as a dove indicates that he is the unique representative of the new Israel. ${ }^{20}$

Furthermore in verse 11, the phrase "You are my beloved Son; with you, I am well pleased" must be understood as a combination from Psalm 2:7 and Isaiah 42:1. Psalm 2:7 states "The LORD said to me, "You are my Son" reveals Jesus as the royal Son of God, whereas in Isaiah 42:1 "Behold my servant, whom I uphold, my chosen, in whom my soul delights" reveals Jesus as the perfect servant of God. ${ }^{21}$ On the other side, the word $\alpha \gamma \alpha \pi \eta \tau$ ós

16 Ibid., 35.

17 D. A. Carson and G. K. Beale, eds., Commentary On the New Testament Use of the Old

Testament (Nottingham: Baker Academic, 2007), 120-21.

18 William L. Lane, Mark, 55.

19 Ibid., 56.

$20 \quad$ Ibid., 56.

21 Ibid., 50. 
or beloved has a significant role in the Gospel of Mark. It is because the occurrence of this word always explains the person of Christ as the Son of God, which connects the moment of Jesus baptism with Mark 9:7 in Jesus transfiguration, and also connects with the parables of the tenants in Mark 12:6 which the beloved son of the owner killed. The entire occurrence anticipates Jesus Christ agony on the Cross and finally leads the centurion's confession about the identity of Jesus Christ by saying "Truly this man was the Son of God!" (Mark 15:19). ${ }^{22}$ Edwards said this phrase gives an important understanding because this epithet was never given to any other prophet in the Bible. Abraham was a friend of God (Isaiah 41:8), Moses a servant of God (Deuteronomy 34:5), Aaron a chosen one of God (Psalms 105:26), David a man after God's own heart (1 Samuel 13:14), and Paul an apostle (Romans 1:1). Only Israel (Exodus 4:23) - and the king as Israel's leader (Psalms 2:7) - had been called God's Son before. But where Israel failed, Jesus takes its place. ${ }^{23}$

The significant account of Jesus's baptism can also be seen by syntax analysis. Mark using aorist tense for three verbs in verse 9 which are

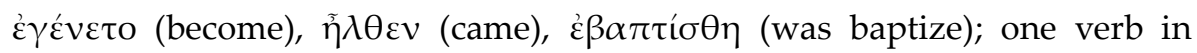

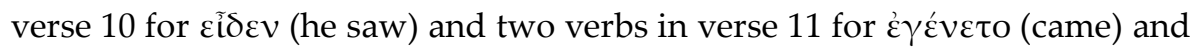
$\varepsilon \dot{\delta} \delta$ ó $\eta \sigma \alpha$ (I am well pleased). The using of aorist tense gives emphasize to the singularity of the event, and because of that, the moment of baptism gives theological significance in Jesus Christ.

In the wilderness context Jesus is baptized, and at that moment heavens are being torn open, the Spirit is descending on him like a dove, which signifies the new creation and is followed by the voice from heaven. All of these events show very clearly that the paradise is regained in Jesus Christ. The communication and relationship with God which were broken

22 Udo Schnelle, Theology of the New Testament (Grand Rapids: Baker, 2009), 406-07.

23 James R. Edwards, Mark, 38. 
by Adam's transgression is restored perfectly in Christ because he is the only one who could please the Father as the perfect long-awaited redeemer in the new exodus context and as the unique representative of new Israel. The voice from wilderness had been answered by the voice from heaven because of Jesus Christ. And in Him, the people of God not only have the assurance of eternal salvation or the full sense of paradise. The place where the people of God could exercise the perfect relationship with Him in his dwelling place at the end of time, but also the possibilities to exercise paradise in Jesus Christ at the present time in the wilderness. It is because in Christ the people of God already has relationship towards the Father but not yet in the full sense.

\section{The Temptation of Jesus}

The account of baptism with highly paradise description moves quickly to the temptation scene in the wilderness. The Spirit who descends on Jesus at baptism drove or sent (NIV) him out into the wilderness immediately, not directly into temptation, 24 but to confront Satan. ${ }^{25}$ Edwards also said that temptation is not presented as an unfortunate circumstance or as a hardship resulting from a lapse or failure on Jesus's part, but it is a necessary corollary lest Jesus be imagined a divine clone or automaton who had no choice or desire of his own. ${ }^{26}$ And because of that, the account of temptation shows that Jesus is truly human with the sovereign will to respond. The imagery is also reminiscent of the scapegoat loaded down with the sins of Israel and expelled into the wilderness (Leviticus 16:21). ${ }^{27}$ Besides that, the immediateness on this account gives an

\footnotetext{
24 Robert A. Guelich, vol. 34A, Word Biblical Commentary: Mark 1-8:26, Word Biblical Commentary (Dallas: Word, 2002), 38.

25 James R. Edwards, Mark, 38.

26 Ibid., 40.

27 Ibid., 39.
} 
indication of the nature of temptation, which tempts Jesus Christ's status as the Son of God who restores the broken relationship with God to bring salvation to the people of God.

Furthermore, the word drove out or $\varepsilon \kappa \beta \alpha \dot{\alpha} \lambda \lambda \varepsilon \iota$ is a verb indicative present active, which means that the writer portrays an action in the process or a state of being with no assessment of the action's completion. ${ }^{28}$ And because of that, the Holy Spirit not leaves him but be with him continuously

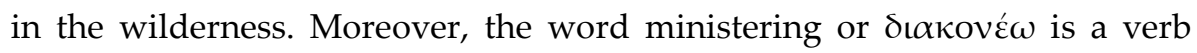
indicative imperfect active is also understood as the continuous action of the angels toward Jesus in the wilderness. On the other hand, the word tempted or $\pi \varepsilon \iota \alpha \zeta o ́ \mu \varepsilon v o \zeta$ is a verb participle presents passive, which also means that Jesus in the wilderness is being tempted continuously by Satan.

From this understanding, the continuous accompaniment by the Holy Spirit in the wilderness and continuous temptation by Satan are not only a single event just as baptism but anticipated the whole ministry of Jesus Christ, until Satan is ultimately defeated when Jesus finishes all the necessary work of salvation. And because of that, the nature of temptation tries to set apart the people of God continuously from their relationship with God in Jesus Christ. But the Holy Spirit will also strengthen the people of God continually not only to overcome temptation but also to have a relationship with God in Jesus Christ continuously or paradise experience in the wilderness continuously.

The important theme of paradise and wilderness on this account can also be seen from several phrases or words that are used in this account such as "wilderness," "forty days" and "with the wild animals." The phrase "in the wilderness forty days" has two significant elements, which are the word wilderness and forty days. The word غ̇ं $\mu \omega$ or wilderness has so many

28 Heiser, M. S., \& Setterholm, V. M. (2013; 2013). Glossary of Morpho-Syntactic Database Terminology. Lexham Press. 
important meanings in the Old Testament it is because the wilderness not only talks about inhospitable habitat but also talks about Israel's relationship towards God in the exodus. The account of Jesus's baptism which has new exodus motives as we already discuss above will give us a very strong basis to relate the account of Jesus temptation in the wilderness forty days towards Israel's experience in the wilderness forty years.

In the first exodus, the very reason why God bring his people out from Egypt were to worship him in the wilderness by giving offering or sacrifice to the LORD their God (Exodus 3:18; 5:1) and indeed, the mountain of God was in the wilderness (Exodus. 4:27; 18:5). ${ }^{29}$ In the wilderness God molds and tests them so they can live according to his will and his commandment, depending only on him and the fear of him may be before them so they may not sin (Exodus 15:25; 16:4; 20:20). But in the wilderness, the people of Israel failed to trust God and to depend only on him.

They believe they would die in the wilderness in the hand of the Egyptians (Exodus 14:11-12). They also grumble with Moses the servant of God because they had no water to drink and believed they would die (Exodus 15:24; 17:2-3). Even worst, they hoped that they had died by the hand of the LORD in the land of Egypt rather than die in the wilderness because of hunger (Exodus 16:2-3). But the LORD still provides them water and food from heaven (Exodus 16:4) but finally they spoke against God and Moses by despised the providence of God who protected and nurtured them and also wanted to go back to Egypt (Numbers 14:1-4; 21:5). And because of that God punish the people of Israel forty years in the wilderness because they did not believe that the LORD will give them the Promised Land (Numbers 14:28-35). Even so, the punishment and scarcity in the wilderness were meant to teach them how to live depending only on God and live

29 Myers, A. C. In The Eerdmans Bible dictionary, (Grand Rapids: Eerdmans, 1987), 1056. 
according to his commandment in humbleness of heart even once they will live in prosperity and abundance in the promised land (Deuteronomy 8:220).

From this understanding, wilderness for the people of Israel also means as an experience how to live in the absolute dependence upon God and in the perfect relationship with God. By learning to do this, they may live and have possibilities to overcome any temptation in the wilderness and to prepare their heart to only long for God and nothing else.

In contrast to the first exodus, the forty-day trial of God's Son continues the baptismal theme of Jesus as Israel reduced to one, ${ }^{30}$ and shows Jesus Christ perfect relationship towards the Father and serves as the proof of his status as the Son of God. William L. Lane said that the word

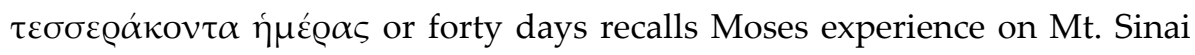
forty days and nights (Exodus 34:28) and Elijah experience which led for forty days and nights to Mt. Horeb without food (1 Kings 19:4-8). In their case, the time of the forty days concentrates into one crucial period the innermost quality of their mission. And because of that, he said that the forty days do not describe a period whose significance is exhausted once Jesus begins his public ministry but sounds the dominant note of his entire ministry. ${ }^{31}$ While Edwards said that the wilderness was a proving ground, a test of faithfulness, and a promise of deliverance. The same contrasts are present in Jesus' temptation because in the wilderness Jesus is both tempted by Satan and attended by angels. ${ }^{32}$ Besides all of that, in the new exodus context the forty-days trial of Jesus Christ in obedience redeems the forty days of Israel in disobedience when Moses sent 12 spies to spy out the land, which at the end causes God's punishment for them to stay in wilderness for forty years (Numbers 14:34).

\footnotetext{
30 James R. Edwards, Mark, 40.

William L. Lane, Mark, 60.

James R. Edwards, Mark, 40.
} 
The phrase "with the wild animals" is unique because it has no parallel with another gospel. The wild animals or beasts already mentioned several times in the Bible both in peaceable and hostile context. In Genesis 2:19-20, the LORD God brought every beast of the field and every bird to Adam and saw how Adam would call them. By doing this, God gives authority to Adam over all creatures, where it resembles the authority of man over all creation in Genesis 1:26-28. In Eden or Paradise man lives in harmony with nature including wild animals or beast. But when Adam disobeys God, humanity enters to the wilderness experience because Adam is cast out from Eden and the land was cursed by God. At that moment humanity and wild animals can't live together in harmony or even more become a threat to humankind. And because of that, there were two interpretations towards this phrase.

First, in the light of Genesis 1:28; 2:19-20, Guelich said that Jesus' presence with the wild animals points to an Adam-Christ typology; it is because of $\mu \varepsilon \tau \alpha$ with the genitive, indicates that Jesus was living peaceably with the animals, a relationship found only at creation. ${ }^{33}$ And because of that the occurrence of "wild beast" and "Angels" suggest a setting in Paradise or serve as paradise motives that may underlie the Markan tradition. ${ }^{34}$ Furthermore, Isaiah 11:6-9; 65:17-25 and Hosea 2:18 show the expectation for the age of salvation or the new creation by picturing the relationship between human and wild animals living in harmony. ${ }^{35}$ And because of that Jesus peaceful coexistence with the wild animals in the wilderness declares that the age of salvation and new creation is fulfilled in Christ. Indeed, it is a very strong argument when we notice that the account

33 Robert A. Guelich, Mark, 38.

34 Ibid., 38.

35 Ibid., 38. 
of Jesus's baptism as we already discuss also brings new exodus and new creation motives.

The second interpretation of this phrase tends to describe wild animals as the symbols of horror and danger which also has an alliance with Satan. It is mentioned in the Testament of Naphtali 8:4 "The devil will flee from you; wild animals will be afraid of you, and the angels will stand by you," which has a close parallel with Mark 1:13. And because of that, R.T France said it indicates that a very early reader understood the wild animals as part of the opposing forces, not as a symbol of Edenic harmony. ${ }^{36}$ Furthermore, Edwards said that the reference to the wild beast is a very particular point of contact with Mark's Roman readers. It is because Tacitus spoke of Nero's savagery toward Christians in the sixties of the first century in these words: "they were covered with the hides of wild beasts and torn to pieces by dogs" (Ann. 15.44). ${ }^{37}$ And because of that, Edwards said the phrase "with the wild beasts" is placed to remind his Roman reader that Christ, too, was thrown to wild beasts, and as the angels ministered to him, so, too, will they minister Roman readers facing martyrdom. ${ }^{38}$

From these two interpretations, we can see that the phrase "with wild animals" can be understood as either serving as the paradise motives or as the wilderness motives. But I would argue that this phrase serves as paradise motives in the wilderness. It is because in the gospel of Mark, Jesus is described as the Lord over all creation. Implicitly in the account of Jesus's temptation, and explicitly it shows all over the gospel of Mark. For the example, Jesus shows his authority over unclean spirits, and they not only obey him but also confess that he is the Son of God (Mark 1:23-27; 3:11; 5:214; 9:25). Even more, he gives his disciple the authority over the unclean

\footnotetext{
36 France, R. T. The Gospel of Mark: a commentary on the Greek text (Grand Rapids; Carlisle: Eerdmans; Paternoster, 2002), 87.

37 James R. Edwards, Mark, 41.

38 Ibid., 41.
} 
spirits (6:7), and because of that, the understanding of Jesus Christ's victory over Satan implies implicitly in the account of Jesus's temptation. Jesus also shows his authority over nature. It is when he rebukes the wind and the sea (4:36), multiplies the loaves and fish to give food for five thousand men (6:41-44). He also walks on the water (6:49), curses the fig tree (11:12-14, 20), and he shows his authority upon animals and unclean spirit when he gives his permission upon the unclean spirit to enter a great herd of pigs (5:10-13). From this understanding, the hostile relationship between Jesus and wild animals clearly is not possible and because of that the presence of paradise does not depend on the situation, but on the presence of Christ himself.

So if Christ is present in a person's life, then they will have paradise experience in the wilderness. It is because only in him a person could have a perfect relationship with God as our Father and enable a person to live in harmony according to his law. By this understanding, the reader of Mark while facing great tribulations under Nero's savagery or wilderness will continue to have paradise experience in Christ. The wilderness experience in relation to the nature of temptation will pull away his people from God, but just as what Paul said in Romans 8:35-39 that were nothing could separate his people from the love of Christ. It means Christ is always with his people, and it is the reason why so many prophets and apostles exercise real joy in the face of great suffering and tribulation. For the example, the apostles rejoicing that they were counted worthy to suffer dishonor for the name of Christ (Acts 5:41). Paul and Silas in the middle of persecution were praying and singing hymns to God (Acts 16:25), and Habakkuk in the threat of scarcity rejoice in the LORD, who is his strength (Habakkuk 3:16-19).

\section{Being Jesus Christ Disciples}

After the account of baptism and temptation, Jesus Christ proclaims that the time is fulfilled, and the kingdom of God is at hand; repent and 
believe in the gospel (Mark 1:15). This statement not only confirms what John already said about Christ in Mark 1:7-8 but also implicitly serves as confirmation of his status as the Son of God. The one whom the Father is well pleased and brings the age of salvation with all the new creation and the new exodus motives as the long-awaited redeemer, and the victory over Satan in the account of temptation. After that, directly Mark shows the calling of the first disciple by Christ.

In Mark 1:17, Jesus said: "Follow me, and I will make you become fishers of men." The nature of this calling is unique because there are no rabbinical stories analogous to the calling of the disciples by the summons "Follow me." 39 And Edwards also said that "in the OT the idea of following God is rare, if not absent because neither Moses nor the kings nor the various man of God nor the prophets will call the people, as a rule, to follow them. The summons, rather, is to walk in God's ways and according to his statutes (Deuteronomy 5:30). ${ }^{40}$ But what Jesus did was calling his disciple to himself, and because of that the calling to the four fishermen is rooted not in the Torah, nor even in the name of God, but in Jesus messianic authority alone. ${ }^{41}$ The nature of discipleship is his calling to himself and only through discipleship one can participate in the Kingdom of God and experience the perfect relationship with God in Christ.

Dallas Willard said that the greatest problem in contemporary churches can be explained by the fact that the members have not yet decided to follow Christ, and because of that, filled the Churches with undiscipleddisciples. ${ }^{42}$ This is the contrary condition from the Great commission that Jesus gives to all believers to make discipleship as the condition to follow him (Matthew 28:18-20). And it is also the contrary condition to the cost of

\footnotetext{
39 Ibid., 49.

40 Ibid., 49.

41 Ibid., 50.

42 Richard J. Foster and James Bryan Smith, eds., Devotional Classics: Selected Readings for Individuals and Groups (San Francisco: HarperSanFrancisco, 1993), 14.
} 
discipleship that he mentions to follow him (Matthew 8:18-22; 10:37-39; Mark 8:34-38; Luke 14:25-27). And because of that, everyone who did not follow him as his true disciple is not his disciple at all and has no possibilities to reconcile with the Father in Christ. It is also no possibility at all to live in harmony according to his law, as what Paul says in Romans 8:78 "For the mind that is set on the flesh is hostile to God, for it does not submit to God's law; indeed, it cannot. Those who are in the flesh cannot please God." It means without discipleship a person may not be able to enjoy the paradise experience in the wilderness at present time nor assurance of eternal salvation or the full sense of paradise where the people of God exercise the perfect relationship with him in his dwelling place at the end of time.

\section{Wilderness Contemporary Societies}

The significance of being the disciple of Christ is to show that we are truly the sons of God as Jesus Christ's disciples. It means to follow Jesus and do his commandment wholeheartedly, as what on the opening phrase from the Lord prayer, that "His will be done on earth as it is in heaven" (Matthew 6:10). Leon Morris said it points to no passive acquiescence but to an active identification of the worshiper with the working out of the divine purpose, on the way Jesus used it (Luke 22:42). In heaven, God's will is perfectly done now, for there is nothing in heaven to hinder it, and the prayer looks for a similar state of affairs here on earth. ${ }^{43}$ Being his disciples means to bring the heavenly presence of God actively by doing his will or bring paradise in the wilderness, even though the consequences are difficulties and misery. Interestingly, that is exactly as what Paul said "that I may know him and the power of his resurrection, and may share his sufferings, becoming like him

43 Leon Morris, The Gospel According to Matthew (Grand Rapids; Leicester: Eerdmans; InterVarsity Press, 1992), 145. 
in his death, that by any means possible I may attain the resurrection from the dead" (Philippians 3:10-11). And because of that, it is our calling as the sons of God to show and proclaim the Gospel in all aspects of life to the wilderness contemporary societies, which means to all those who are still enslaved in sins, who are not reconciled yet to the Father in Christ and still lives in the darkness.

After being Jesus Christ's disciples and living in him, our broken relationship is restored. From that moment we can start to love God with all our heart, soul and mind. And according to Bernard of Clairvaux, to love our neighbor, we must see that God is the cause of our love. And because of that, God must be loved first in order we may love our neighbor in God. ${ }^{44}$ And even to love our enemy as what Jesus said "Love your enemies and pray for those who persecute you, so that you may be sons of your Father who is in heaven" (Matthew 5:44). The sons of God may also know when they are being the peacemaker (Matthew 5:9). Morris said peacemaker is the people who end hostilities and bring the quarrelsome together and actively overcome evil with good through his whole sphere of life..$^{45}$

From this perspective, Jesus Christ's disciple not only able to lives in harmony toward God but also toward their neighbors, and enemies. And because of that, Christ's disciple will bring paradise in the wilderness, in all sphere of life. Furthermore, together as the body of Christ, the disciples will fulfil God's will in earth as it is in heaven, being of the same mind, having the same love, being in full accord and of one mind, who are not looking for his interest only, but also the interests of others and more importantly the interest of Jesus Christ. (Philippians 2:2-4). In this understanding, bring the paradise in the wilderness is not an individual work but collective work as the body of Christ until the second coming of Jesus Christ. And as the

44 Richard J. Foster and James Bryan Smith, eds., Devotional Classics, 41.

45 Leon Morris, Matthew, 101. 
consequences, this perspective would avoid the tendency of Church splits into many denominations.

On the other hand, the paradise in wilderness perspective would also avoid the temptation of Christendom because bringing the paradise in the wilderness is not talking about changing physical condition, although it may impact, but to present Christ actively in wilderness contemporary societies, so they may know Jesus and saved by his grace. Just as what Jesus said "Foxes have holes, and birds of the air have nests, but the Son of Man has nowhere to lay his head" (Matthew 8:20). Even though the presence of paradise does not depend on the situation, but by the presence of Christ himself, this statement signifies his ministry in the wilderness even more austere than the lives of birds and foxes. ${ }^{46}$ And because of that, it is the nature of our calling to present Christ in the wilderness that we may face so many difficulties, struggles or even tribulations, but in all these things we are more than conquerors through him who loved us (Romans 8:37).

46 Blomberg, C., Matthew Vol. 22, (Nashville: Broadman \& Holman, 1992), 146. 